УДК 141.32

DOI: $10.21209 / 1996-7853-2020-15-2-66-75$

\author{
Алексей Николаевич Фатенков, \\ Национальный исследовательский \\ Нижегородский государственный университет им. Н. И. Лобачевского \\ (г. Нижний Новгород, Россия); \\ Приволжский исследовательский медицинский университет \\ (г. Нижний Новгород, Россия), \\ e-mail: fatenkov@fsn.unn.ru
}

\begin{abstract}
Антропологическая вертикаль: власть характера над амбициями и интересами
В центре внимания автора - ценность характера, понимаемого экзистенциально-натуралистически. В методологии ставка сделана на экзистенциальный реализм, представляющий собой диалектическое единство инструмента-метода и онтологического основания авторского исследования. Выстраивается антропологическая вертикаль, вершину которой занимает человек с характером со свойственной ему здравой иррациональностью. Он противопоставляется человеку с амбициями и человеку с интересом. В отличие от них, существ собственно социальных, человек с характером - существо по преимуществу экзистенциальное с анормальной, избыточной или недостаточной, социальностью. Он жизненно противоречив. Одновременно - и непритворно нравственен, без ссылок на нормы общественной морали, и пребывает по ту сторону добра и зла. В контексте событий 1917 г. обсуждается роль человека с характером в социальной революции. Фигурой первого плана берётся тут В. И. Ленин. Используя неконформистские свидетельства Н. А. Бердяева, Н. В. Валентинова (Вольского), Г. В. Вернадского, М. Горького, В. Сержа, Н.Н.Суханова, Н. В. Устрялова, конкретизируется портрет лидера большевиков как человека с сильным характером при минимуме амбиций. Подчёркивается, что именно это сущностное качество позволяет органически сопрягать полярности человеческой натуры и продуктивно действовать, не подчиняясь рассудочным шаблонам. Антропологическая трагедия революции видится автору в том, что сражаются и гибнут в ней характерные, а плоды пожинают амбициозные и редуцирующие всё к интересу. Делается вывод о приоритетной роли характера в практике сохранения и укрепления человеческого достоинства.
\end{abstract}

Ключевые слова: антропологическая вертикаль, человек с характером, человек с амбициями, человек с интересом, здравая иррациональность, революция

\author{
Aleksey N. Fatenkov, \\ Lobachevsky State University of Nizhny Novgorod \\ (Nizhny Novgorod, Russia); \\ Privolzhskiy Research Medical University \\ (Nizhny Novgorod, Russia), \\ e-mail: fatenkov@fsn.unn.ru
}

\title{
Anthropological Chain: Power of Character over Ambitions and Interests
}

The value of character interpreted in an existential and naturalist way is in the focus of author's attention. In methodology the author relies on an existential realism which is a dialectic unity of an instrument-method and ontological basis of the research. The anthropological chain which top is occupied by a man of character with his characteristic healthy irrationality is being constructed. He is being opposed to a man with ambitions and a man with interest. Unlike those essentially social creatures, man with character is a mostly existential creature with abnormal, excessive or insufficient, social nature. He is vitally contradictory. He is simultaneously - and truly moral without references to norms of public morality and finds himself beyond good and evil. The role of man with character in a social revolution in the context of 1917 events is discussed. V. I. Lenin is taken here as a forefront figure. Using nonconformist testimonies of N. A. Berdyaev, N. V. Valentinov (Volsky), G. V. Vernadsky, M. Gorky, V. Serge, N. N. Sukhanov, N. V. Ustryalov, the author specifies the portrait of Bolsheviks' leader as a man with the strength of character and minimal ambitions. It is pointed out that this essential quality allows us to combine polarities of human nature inherently and to act efficiently while not submitting to rational patterns. The anthropological tragedy of revolution is seen in the fact that characters fight and perish in it but rewards are reaped by those who are ambitious and reduce everything to interest. The conclusion is made about prioritized role of character in the practice of human dignity preservation and promotion.

Keywords: anthropological chain, man with character, man with ambitions, man with interest, sane irrationality, revolution

(C) Фатенков А. Н., 2020 
Введение. Существительное и прилагательные. Мне говорят: «Ты возвеличиваешь характер, - что правда, - а ведь он бывает и несносным, эгоистичным, завистливым, капризным, подлым». Не стану второпях парировать иными случаями - встречами с характером стойким, отзывчивым, самоотверженным. Каждое прилагательное, добавляя частности, штрихи, детали, расшатывает существо содержания, то, которое просится в строку, как у немцев, с прописной буквы. Но и в обычном, строчном написании имён существительных кроется немалый смысл: намёк на неброское достоинство, на уверенную в себе скромность. Она и позволяет прилагательным вносить некоторое уточнение в то, что, по глубокому уму, способно обойтись без явно выраженной конкретизации.

Поэтому о «здоровом» характере только вначале, лишь для того чтобы сходу, без погружения в скрытые смысловые пласты, противопоставить однозначно ценное наличие в человеке экзистенциального стержня двойственности его отсутствия. Бесхребетность индивида аномальна в контексте нонконформизма и нормальна, даже удобна, в конформистской проекции. Характер же вообще не признаёт критерия удобства, иначе сказать - с характером неудобно нигде и никогда. И часто не разобрать, кому беспокойно в особенности: его владельцу или тем, кто того окружает. Полярность конформизма и нонконформизма для характерного человека не очень важна, относится он к ней не без иронии: один её элемент - унизительно смешон, другой претенциозно высокопарен.

Возникает, естественно, вопрос о соотношении бесхарактерности с характером негативным: что лучше, иметь его или не иметь никакого? Ответ, впрочем, дать не сложно: уж лучше какой-нибудь, пусть и с серьёзными изъянами, - для того, разумеется, кто не ищет забвения и не собирается плыть по течению, хотя бы течение это оказалось самим совершенством. Шанс залатать прорехи, избавиться от недостатков - невелик (не надо множить иллюзии), но всё-таки есть. А из отсутствия, из ничто, даже непорочного, ничего не выйдет и не вытечет, никакой ручеёк совершенства.

Методология и методы исследования. Приоритет отдан здесь экзистенциальному реализму, представляющему собой диалектическое единство инструмента-ме- тода и онтологического основания авторской работы (подробнее см.: [12, с. 48-49]).

Результаты исследования и их обсуждение. На семантическом кусту фрилософских категорий «характер» находится рядом с «природой (происхождением)», «сущностью», «самостью (Я)» и «экзистенцией». Характер - это сущность, с нарастающей конкретизацией перетекающая из природы в самость. Событийно он связан с экзистенцией. Та распознаётся и понимается как существование, становящееся сущностью; характер - как сущность, обречённая на существование. Данное толкование добавляет градус трагедийности в содержание дефиниции Освальда Шпенглера: согласно той, характер есть «форма подвижной экзистенции, в которой при максимально возможной изменчивости в частном достигается наивысшее постоянство в принципиальном...» [15, с. 498].

Самое сильное, что написано и прочитано о характере (теперь и далее - без всяких прилагательных), с чем соглашаешься безоговорочно и с чем местами решаешься спорить, встретил у Эрнста Юнгера. Доброволец Первой мировой, окопный лейтенант - он из поколения моего деда (тут много личного). Нижеследующие выкладки, в немалой их части, выстроились в процессе-состоянии соразмышления с этим немецким философом. Его позиция по обсуждаемому вопросу куда более жёсткая, нежели у идейно близких ему Ф. Ницше и М. Хайдеггера. Тех академически смущает погружённость характера, германского особенно, в кровь и почву. Человека, пролившего кровь за родную страну (11 ранений), не смутить ничем. По Юнгеру, если сжато, характер - от природы, не от воспитания; от сердца, не от рассудка; от судьбы, не от причинно-следственной канители ${ }^{1}$. Если цитатно: «Характер - главное в нас; он наша подлинная стихия, внутренний неложный образ, чьим внешним запечатлением является наша жизнь. <...> Характер “процарапывается" в человеке раз и навсегда. Над ним не властны законы прогресса, только законы развития»².

Да, характерность - та же натурность. Вернее, сосредоточенная натурность: весьма значима в ней конкретная наследственная компонента. Кто бы что ни гово-

${ }^{1}$ См.: Юнгер Э. Характер // Националистическая революция. Политические статьи (1923-1933) / пер. с нем. А.В. Михайловского. - М.: Скименъ, 2008. C. $71-76$.

$$
2 \text { Там же. - C. 72-74. }
$$


рил о роли воспитания. Воспитывается, как и воссоздаётся, только то, что в основе своей уже заложено и, вместе с последующими заимствованиями извне (в первую очередь, опять же, от людей близких), взращивается твоими собственными, не чьими-то, небезрассудными волевыми усилиями. Всё точь-в-точь как со свободой: «Свободным нужно быть, чтобы стать таковым...» [16, c. 130]. Декларируемый оппонентами примат внешнего воздействия - просвещенческий, механистического толка предрассудок с его всегдашней подозрительностью к индивидуальной воле, допускаемой лишь в качестве слагаемого воли общей, которая видится изначально подчинённой некой разумной необходимости. Конечно, и природа полна необходимо происходящим но она полна и желанным, которое заведомо не вписывается без остатка ни в одну логику. Судьбоносна и характерна наша любовь к природе. «Именно она в форме полового влечения составляет существеннейшую часть человека» ${ }^{1}$. От елейного морализаторства оборону будем держать тут вместе и с Конрадом Лоренцем - Нобелевским лауреатом, за плечами которого стойко преодолённые тяготы войны и плена. Из его этологических изысканий и целостного, личностного осмысления жизни следует: «Человек, избавленный от всего так называемого "животного", лишённый влечений, исходящих из тьмы, человек как чисто разумное существо был бы отнюдь не ангелом, а скорее его полной противоположностью!» [7, с. 282].

Характер, плох он или хорош, не отчуждаем от действующего или созерцающего субъекта ни при каких обстоятельствах - в отличие от логической формы мысли, от манеры высказывания и поведения: те можно тиражировать и навязывать окружающим, можно скопировать и украсть. Напротив, пронизанные характером слово и дело - всегда в тебе, а ты - в них. Добро и зло, также по существу своему характерные, истекая из человеческого нрава, остаются в нём, делая индивида нравственным или безнравственным. Не существует ни универсального морального закона, ни внеморального и вненравственного прочтения юридических норм. «Каждый закон определяется характером, императивом крови. <...> Убийство из ревности перед лицом норвежского правосудия -

${ }^{1}$ См.: Юнгер Э. Характер // Националистическая революция. Политические статьи (1923-1933) / пер. с нем. А. В. Михайловского. - М.: Скименъ, 2008. - С. 72. одно, а перед лицом итальянского - другое» ${ }^{2}$. Взятые в отвлечении от природноэкзистенциального стержня субъекта добро и зло усыхают до пропозиций, вариативно заполняемых общественной моралью, извечно прислуживающей власти и усердно обрабатывающей подданных (не важно, строгими запретами или провоцированием распущенности).

Жизненный опыт подсказывает вычертить определённую антропологическую вертикаль: человек с характером - человек с амбициями - человек с интересом. Последний - расчётливый до цинизма индивид массового покроя с нехваткой воли и упрямства, с худосочной мечтой о страховке на все случаи жизни. Закон «возвышения потребностей» (и нагнетания интересов, стало быть) написан для него, бухгалтерски правильной персоны. Над ним и над всей людской массой пытается возвыситься человек с амбициями: столь же расчётливый и с тем же дефицитом воли, но не чуждый риска и авантюр, он, тщеславный и не без черт упрямства, играет на слабостях рассудочно-опасливых обывателей, зачастую не замечая наличия этих же слабостей в себе. Иное дело - человек с характером: предельно требовательный к себе, он, опираясь на разумную волю, подкрепляя её порой «бараньим» упрямством, действует в отношении себя и других вопреки тенденциям омассовления: властвует - прежде всего над собой, любит и ненавидит - невзирая на обстоятельства.

Человек с интересом не интересен - не притягателен - по существу. Всего-навсего рассудочная марионетка из той же оптической плоскости, что и павловская собака и фордовский конвейер. Оперирующий интересами, мысленно и практически, абстрагируется от добра и зла (ср.: [14, с. 77]) - но не в силах прорваться по ту их сторону, не способен достичь бесценного. Задача решается иная: редуцировать ценности к ценностным отношениям, а те - к отношениям стоимостным. Формат купли-продажи по максимуму релевантен ожиданиям и поведенческому стандарту человека с интересом, приводя его вместе с тем к состоянию перманентной зависти. Дистанцирование от добра и зла позволяет завистливому паллиативно, не более, избавлять себя от удручающей самооценки. Сущность свою ему, однако, не скрыть. Мелочному, калькулирующему всё и вся индивиду харак-

\footnotetext{
2 Там же. - C. $73-74$.
} 
терно отвечает Луи-Фердинанд Селин: «Я терпеть не могу торговаться из-за каждого су, кассовая ненависть у меня в крови <...> чёрт побери! скорее кассовое чутьё... оно у всех людей такое обострённое!.. нечеловеческое! почти звериное!..» ${ }^{1}$. Интересу содержательно противостоит не столько незаинтересованность, сколько бескорыстие. А ещё - щедрость и дар. Не поддаются они подсчёту - ни замшело мещанскому, ни инновационно сциентистскому.

Человек с интересом - продукт и типаж капиталистических общественных отношений (актуально или потенциально наличествующих). Критикуя советский опыт, деформированный НЭПом, Эрнесто Че Гевара справедливо отмечал, что «рычаг материального интереса при социализме... не способен ни заставить загореться глаза самых жаждущих, ни преодолеть безразличие остальных» ${ }^{2}$. Расширяя геваровский тезис, имеет смысл утверждать, что и нематериальный интерес подчиняется, так или иначе, закону стоимости, а стало быть, генерирует, воспроизводит и реставрирует капиталистическую систему. Социализму не справиться с ней, пока он оставляет человека в формате интересов. Непобеждённый до сих пор кубинский социализм не случайно связан с характером страны. Да, Куба - это «тропическая, неукротимая, наивная и радостная страна» ${ }^{3}$. Природа там щедра, и чувства не в кабале у рассудка.

Понятно, атаку на интерес многие воспримут в штыки, ведь под сомнение ставится доминирование рационального в человеке и обществе. Подчеркнём, ставится под сомнение ответственно. А потому ещё несколько отчаянно упрямых выкладок. Интерес - это осознаваемая потребность. Однако не факт, что в интересе потребность осознаётся адекватно, при том что адекватное её осознавание не гарантирует защиты от падения в цинизм. И дело здесь не только в недостатках разума - в его инструментальности, амбивалентности, всеядности, - но и в онтологической ущербности самой потребности, всегда свидетельствующей о нашей бытийной неполноте и несвободе. Где потребность, там исподволь проступает нужда. Там в открытую правит

1 Селин Л.-Ф. Из замка в замок: роман / пер. с фрр. М. Климовой и В. Кондратовича. - Харьков: Фолио; М.: АСТ, 1999. - С. 97.

2 Че Гевара Э. Статьи, выступления, письма / пер. с исп. Е. Вороновой [и др.]. - М.: Культурная революция, 2006. - С. 551.

${ }^{3}$ Там же. - С. 544. необходимость... или её иллюзия, отказаться от которой, как выясняется, ничуть не проще, чем от фрактически необходимого. Культ потребностей и интересов неминуемо ведёт к обществу потребления... Оно складывается там и тогда, где и когда необходимость и её иллюзия становятся неразличимы. И осознание этой неразличимости, даже будь таковое возможным, ни на шаг не продвинет нас в сторону свободы, не избавит от пут её призрака, если человек не проявит характер, граничащий порой с безрассудством, если не станет грести против течения, не поднимется на протест. Не мельтеша - с достоинством. И обуздывая амбициозность.

Человек с амбициями - суетлив. Человек с характером - ценит неспешность. Один - пронырлив и изворотлив, но, как ни старается, предсказуем в своих схематичных действиях. Другого - неманерно глубокого, характерного, действующего по интуиции и ощущениям - до конца не просчитать. Человек с характером - может и превозмогает. Человек с амбициями - домогается. Должности, власти, женщины чего и кого угодно. Он дока в причинных связях и отношениях, но не сведущ в основаниях, лишён их - и потому поверхностен и ненадёжен. Напротив, характерный индивид не причиняет, а обосновывает; он, укоренённый в бытии, неподдельно надёжен. Подспорьем ему служит не мораль, не право, не идеология, всегда социально и политически конъюнктурные, а природная упёртость, сдобренная нравственной интуицией экзистенциального порядка.

От срывов, разумеется, никто не застрахован, они случаются (жизнь есть жизнь) - но не по расчёту, а под напором иррационального, того же «основного инстинкта» чаще всего. Речь не о патологии (чётко распознаваемой и отторгаемой нравственным чутьём - и конъюнктурно ретушируемой, превращаемой в товар морально-правовыми спекуляциями): к ней-то как раз предрасположены амбициозные. Речь о том, за что, сделанное, будешь себя корить - но станешь корить и за то, если не сделаешь, пройдёшь мимо, поосторожничаешь. Выйти из правового поля (или вернуться в древнее), чтобы ответить око за око. Не заметить моральных преград, резонансно совместить вершины нравственности и безнравственности - и провести ночь с любимой женщиной, не оглядываясь на её и свои семейные обязательства. Ни от- 
некиваться, ни оправдываться, ни слезливо каяться потом ни к чему. Где всепоглощающее чувство, там выжженная земля. Если не в эпицентре, то вокруг. Фридрих Ницше категоричен: любовь варварски выделяет одного из всех, и всё, что делается из неё, совершается за гранью морального и неморального (см.: [8, с. 78, 92]). Альбер Камю предельно обостряет тезис: тот, кто не решается ранить людей, остаётся навеки бесплодным; «в конечном счёте любить одного человека - значит убивать всех остальных» [6, с. 320]. Не исключено... Атрибутивное противоречие характерного человека между двумя нераздельно-неслиянными его ликами: непритворно нравственного существа, ничуть не озабоченного своей моральной образцовостью, и пассионария, пребывающего по ту сторону добра и зла. Или, иначе, это противоречие между сердечностью и брутальностью; между героями Дж. Д. Сэлинджера и Э. Хемингуэя (имея в виду литературную проекцию). Стильное его снятие отыскивается в геваровской линии: становиться грубее, сохраняя в себе свою нежность.

Рассмотренные антропологические типы различаются таким образом, что человек с амбициями и человек с интересом - существа собственно социальные (тут далеко до Марксова оптимизма касательно эмансипирующего потенциала общества), тогда как человек с характером существо по преимуществу экзистенциальное со свойственной ему анормальной социальностью: либо избыточной (у вождя и мессии), либо недостаточной (у бунтаря и строптивца). Вождь жертвует своей экзистенцией, подчиняя её общественному служению. Мессия хранит экзистенцию, жертвуя собой. Оба они на авансцене общественной трагедии. Бунтаря и строптивца нередко обнаруживаем в координатах провинциального городка или тропической глуши. Между собой эти ффигуры разнятся формами протеста и схожи формой трагедийности: их победы априори временны, в то время как вождь и мессия грезят эпохальным, или даже вечным, светлым будущим. Строптивец порой перебарщивает с экспрессией (Митя Карамазов), бунтарь - с рассудочным самоедством и чертовщиной (Иван) или с молчаливым поцелуем в ответ на чьё-то неприятие мира (Алёша, тёзка). Но именно они - живее всех живых. Их не превратить ни в мумию, ни в икону.
Выстроенная антропологическая вертикаль отчётливо просматривается в период социальных переворотов: революция на подъёме, когда в её авангарде люди с характером; революция идёт на спад, когда характерные деятели подменяются амбициозными; от революции не остаётся и следа при доминировании в обществе человека с интересом. Наступивший эволюционный период вновь сменяется предреволюционным отрезком истории, когда задавленные и соблазнённые пирамидой интересов, спеленованные рутиной повседневности осмеливаются поддержать характерных, а те чувствуют поддержку, или хотя бы возможность обретения таковой. Если на поступок решаются единицы, вместо революции получаем бунт. Он, надо заметить, не прекращается и в самые застойные времена: характерность и бунтарство всегда в связке.

Когда говорят о подлинной трагедии революций и гражданских войн, часто справедливо указывают на то, что правда (если не историческая, то человеческая) была за обеими (всеми) противоборствующими сторонами. Иначе сказать: в первых рядах сражающихся друг против друга - люди характерные. И то, что кто-то из них, подобно Григорию Мелехову, менял политические лагеря, свидетельствует не столько об имевших место социальных метаниях этих людей, сколько о том, что их личностно неотчуждаемая правда крепче правды политизированной.

Судьбы Русской революции, гражданской войны, страны, наконец, решались, обострённо персонифицируя ситуацию, в отчаянной рубке - когда действительно некогда всматриваться в лица - красной конницы Думенко и белой конницы Шкуро. Оба - пассионарии. Оба проиграли. Один расстрелян как «чужой» среди своих, другой повешен как «свой» среди чужих. Кто же выиграл в конце концов? Столетие спустя ответ напрашивается невесёлый: уж точно, не шолоховский герой, не натурный и самостоятельный человек. Триумф празднуют сегодня вёрткие субчики, которые, ловко институциализируясь, цинично пользуясь любой подвернувшейся идеологией, изо дня в день гнобят людей. Эксплуатируют исподтишка и по закону, принятому депутатской клакой.

Хрестоматийный «человеческий фактор». Решающий - и в революционную, и в суетливо-вялотекущую эпоху. Поставив 
«фактор» на ноги, очистив его от наносов избыточной неопределённости, получим «вертикаль». В ней - такова прописанная выше авторская гипотеза - имеет смысл выделять три фригуры: человека с характером, человека с амбициями, человека с интересом. Вертикаль, возносящая на вершину характерного индивида, благоволит здравому иррационализму, дистанцирующемуся и от фанатично-мутного иррационализма «не от мира сего», и от оголтелого рационализма, бесстыдно прозрачного в своей примитивной посюсторонности, закономерно подчиняющего жизнь, включая «высшие интересы» людей, расчёту. Легитимация и облагораживание корысти столь же неприглядны, как и фридеистическая девальвация свободного ума. В иррационализме, когда он здравый, кратно больше от нехворой телесности, чем от «душеспасительной» проповеди. И гораздо больше от азартной смышлёности, нежели от калькуляции.

Экстраординарное, революционное состояние общества тем и отличается от размеренного, ординарного, что делает зримым и социально оправданным возвышение здравого иррационализма. «Сознательный пролетарий» на революцию не поднимется, он до скончания века будет искать рассудочно беспроигрышные - тред-юнионистские - варианты конформного существования. Максимально самокритичный рационализм (стало быть, вольно или невольно пересекающийся с иррациональным в человеке) говорит о том, чего нельзя, не следует делать, подразумевая, что всё прочее, не подпадающее под ограничение, разрешено. Здравый иррационализм критичнее любого критического рационализма - до такой степени, что настаивает, в духе нетривиального отрицания отрицания, на вполне определённом, конкретном действии «несмотря ни на что», невзирая на сколь угодно широкий спектр рассудочных возражений.

Два примера. Первый - борьба вернувшегося из эмиграции В.И. Ленина за курс на вооружённое восстание против большинства в руководстве партии. Один из внимательных слушателей «апрельских тезисов», развёрнутых в двухчасовом выступлении в особняке Кшесинской, позднее вспоминал: в той речи было много всего но вовсе не было в ней «анализа объективных предпосылок, анализа социально-экономических условий для социализма в России» [10, с. 12]. Интеллигибельный марксизм социал-демократического фрормата резко отставлен в сторону - и победа пришла! Второй пример - монолог Романа Валерьяновича Хлудова из булгаковского «Бега»: «Ну какое может быть положение на фронте? Бестолочь! Из пушек стреляют, командующему фронтом печку с угаром под нос подсунули, кубанцев мне прислал командующий в подарок, а они босые. Ни ресторана, ни девочек! <..> Положение? Поезжайте... и скажите, чтобы тыловые гниды укладывали чемоданы! Красные завтра будут здесь! И ещё скажите, что заграничным шлюхам собольих манжет не видать! Пушной товар!» ${ }^{1}$. Неслыханно!.. но так оно и есть! - вот формула, приближающая нас к распознаванию здраво иррационального френомена, субъектно порождаемого сильным характером.

Я не сторонник разговоров на тему «что было бы, если бы...» и минимизирую предположения о том, «чего не было бы, если бы...». Но не без исключений. Одно из них касается роли В. И. Ленина в Октябрьском вооружённом восстании и последовавшем социальном перевороте. Убеждён (хилая гипотетичность тут неуместна): не было бы Ленина - не было бы и социалистической революции в России. Речь не о творческом развитии марксисткой теории в новую, империалистическую эпоху и даже не о выдающихся организаторских способностях и твёрдой воле лидера большевиков - всё это в определённом смысле производные от его сущностного качества: сильного характера при минимуме амбиций. Главные соратники-конкуренты - Троцкий и Сталин - уже не той породы. У обоих - зашкаливающие амбиции ${ }^{2}$. И то, что у генсека характер оказался сильнее, чем у оппонента, содержательному развитию революции, органическому перерастанию её из военной фазы в мирную всё равно не помогло. (Органический рост не отменяет здесь как таковую прерывность социального движения - элиминируются лишь, в тенденции, предпосылки к термидору и перерожденчеству). Революционный фрормализм, раскритикованный властью в сфрере искусства,

${ }^{1}$ Булгаков М. А. Бег // Собрание сочинений: в 5 т. Т. 3. - М.: Худож. лит., 1989-1990. - С. 231.

2 В плане культа личности Сталин вторичен. В 1922 г. в устав Красной Армии была включена политическая биография Троцкого, которая заканчивалась словами: «Тов. Троцкий - вождь и организатор Красной армии. Стоя во главе Красной армии, тов. Троцкий ведёт её к победе над всеми врагами Советской республики» [цит. по: 5, с. 287]. 
возобладал, риторически издеваясь над революционным содержанием, в сфере политики. И ещё. Амбиции - это не покрасоваться. Ну какой из рябого и сухорукого красавчик? Амбиции - это жажда власти, безраздельной, которую заведомо не удержать. Сегодняшняя «добропорядочная» мода на Сталина созвучна господствующему ныне безыдейному технократизму, эклектично сочетающему в своём воспроизводстве глобальное и локальное, амбиции и интересы - характера тут кот наплакал. Маргинальная мода на Троцкого - сейчас и раньше - коррелятив беспочвенного классово-космополитического авантюризма (при рельефно критичном толковании); в лучшем случае - мода на великое освободительное начало (как минимум континентального масштаба), которое, при дающей о себе знать нехватке характера у зачинателей, так и остаётся перманентным началом без сколько-нибудь внятного продолжения-завершения.

Прежде чем вернуться к фигуре Ленина, два слова в защиту не присущего и ему «покрасоваться». Ничего априори негативного в демонстративной удали нет - на переднем крае борьбы, само собой, не в штабах. Без героев в смертельной схватке не устоять, не победить.

...У командира молодецкий вид.

Фуражка набок, расхлебастан ворот.

Смекалист, бесшабашен, норовист -

Он чёртом прёт на обречённый город...

Процитирован Арсений Несмелов ${ }^{1}$, один из любимых поэтов. Мне не так важно, на чьей стороне воевал он тогда и в каком политическом лагере оказался бы теперь - лишь бы не в концентрационном. Кратно важнее, что офицерская честь для него выше любых идеологий, а Маяковский столь же ценен, как Тютчев и Достоевский, как сам русский язык:

Не знаю лучшего

Для сквернословий и молитв.

Он, изумительный, - от Тютчева

До Маяковского велик...

Романтизированный реализм, невидимый порой за поволокой цинизма. По факту - воин-поэт активно боролся с большевизмом, отдавая должное противнику: «...Сам Ленин был нашим врагом!».

${ }^{1}$ См.: Несмелов А. И. Стихотворения и поэмы // Собрание сочинений: в 2 т. Т. 1. - Владивосток: Рубеж, 2006. -560 c.
Несколько штрихов к портрету большевистского вождя, «человека с сильным характером при минимуме амбиций». Обращаемся, разумеется, к неконформистским (без лакировки) свидетельствам.

Максим Горький, допуская, что Ленин «понимал драму бытия несколько упрощённо и считал её легко устранимой...», сосредоточивает внимание на других его личностных качествах. В очерке-некрологе читаем: этот человек «изумительно сильной воли» и воинствующего оптимизма во всём остальном был типичным русским интеллигентом со свойственным тому скромным, аскетическим подвижничеством, лишённым внешнего блеска и не поддающимся соблазну честолюбия. И ещё, отмеченные соратником-оппонентом, немаловажные черты: азартен, но не корыстен; по отношению к товарищам - сердечно внимателен, но не манерно заботлив с прицелом и выгодой для себя (см.: [4]).

Неортодоксальный коминтерновец Виктор Серж (Виктор Львович Кибальчич, родители его матери - нижегородцы, знакомые М. Горького). Вот его эскизные, с натуры, зарисовки Ленина: мужчина с «заурядными русскими чертами», «сама простота», «большой крепкий лоб, улыбка человека здорового, знающего истину и уверенного в самом себе», «в его манерах и поступках не было ни малейшего намёка на вкус к власти, только требовательность серьёзного специалиста, который хотел, чтобы работа выполнялась хорошо и вовремя, и открытое стремление уважать новые порядки, вплоть до самых незначительных, казавшихся чисто символическими» [9, с. 127, 213]. Напротив, для сравнения, Зиновьев, второй по партийному стажу в большевистском ЦК, «имел вид чрезвычайно самоуверенный... он просто чувствовал себя на своём месте на вершине власти... однако от него исходило также ощущение дряблости и скрытой неуверенности» [Там же, с. 99]. Без комментариев.

Уже цитированный Николай Николаевич Суханов, меньшевик-интернационалист, симптоматично характеризует ораторскую особенность Ленина: не мастер изящной «круглой фразы», не острослов - «но оратор огромного напора, силы, разлагающей тут же, на глазах слушателя сложные системы на простейшие, общедоступные элементы и долбящий ими, долбящий, долбящий по головам слушателей до бесчувствия, до приведения их к покорности, до 
взятия в плен» [10, с. 11]. Создатель большевистской партии именуется «явлением чрезвычайным», «гением» - и как все гении видится ненормально-узким, не способным постичь многого даже в общественной практике и теории. "Но зато в известной сорере идей - немногих, "навязчивых" идей - Ленин проявлял такую изумительную силу, такой сверхчеловеческий натиск, что его победоносное влияние в среде социалистов и революционеров уже достаточно обеспечивается самими свойствами его натуры» [Там же, с. 21]. Он, утверждает автор «Записок о революции», взял массы бесшабашным радикализмом и разудалой левизной, а партийную братию - приёмами Бонапарта и Макиавелли (см.: [Там же, с. 23-24]). Не исключено, думается, и более глубокое сопряжение левого и правого в ленинизме. Вряд ли все его победы над левым коммунизмом были пирровыми (возразим здесь Н.Н. Суханову). И вряд ли пролетарско-крестьянские массы, «не знавшие иной выучки, кроме царской нагайки», жаждали услышать от взывающего к ним революционера сплошь левую мысль о сущностном равенстве людей, а и не мстительную ещё, перевёрнутую иерархически правую мысль о диктатуре трудового народа.

По оценке евразийца Георгия Владимировича Вернадского, «авторитет Ленина имел решающее значение в партийных делах и делах всей нации с первых дней революции и до последних дней его болезни», при этом большевистский лидер «не терпел помпезности, никогда не демонстрировал свою власть и не разрешал делать это другим». Ленин смело грёб против течения, твёрдо держась выдвинутого лозунга и принятого решения, до тех пор пока не достигал цели или не приходил к выводу о необходимости смены курса. «...Он никогда не боялся остаться один (курсив наш. - А. Ф.)»! В его характере удивительно сочеталось, казалось бы, несочетаемое: непреложный фрормализм и замечательный инстинкт, силы разрушения и силы созидания. «...В одном человеке соединились фанатик и оппортунист» [3]. Как-то всё-таки соединились...

О внутренней противоречивости Ленина, «утописта» и «реалиста», пишет и социалист-эмигрант Николай Владиславович Валентинов (Вольский). На одном полюсе масштабной личности - «хилиазм, революционный раж, свирепость, иллюзионизм, безграничная сектантская нетерпимость, отрицание допустимости каких-либо компромиссов, желание, ни с чем не считаясь, не осматриваясь по сторонам, прямо, кроваво, беспощадно идти к намеченной цели». На другом полюсе - «осторожность, практический нюх, конформизм, хитрость, большая расчётливость, способность, с помощью далеко идущих компромиссов и комбинаций, гибко приспосабливаться к требованиям изменяющейся жизни». Вывод, однако, не комплиментарен: такого рода полярности не сопрягаются, Ленин двоедушен (см.: [2]). Позволю себе не согласиться: полярности, конечно же, могут сопрягаться, более того - возможен их положительный синтез. При наличии в человеке стержня - того, что зовётся характером.

У экзистенциалиста Николая Александровича Бердяева - подключаем его к рассуждениям - нет никаких сомнений: «Ленин сделан из одного куска, он монолитен» [1, с. 95]. И эта крепкая порода, чуждая богеме, целиком вбирает в себя сшибку интеллигента-сектанта и государственника.

Национал-большевик Николай Васильевич Устрялов увидел в Ленине «подлинность нутряной какой-то правды...», своеобразно включавшей в себя - в развороте революционных перипетий - «и прозорливость Мирабо, и оппортунизм Дантона, и вдохновлённую демагогию Марата, и холодную принципиальность Робеспьера» [11, с. 372]. Да, «роковая двойственность», или даже множественность, но без распада - наоборот, в сплетении глубинных различий, в слиянии полярностей. Триумфатор Октября воспринимается автором очерка-памятования «воплощённой стихией революции» и, будучи стихией, пребывающим по ту сторону добра и зла. Он отнесён к числу «фантастов», встающих иногда у руля человеческой навигации, отбрасывая и сметая «людей реальной жизни» (людей с интересом, по-нашему), погружая их в царство призраков (см.: [Там же, с. 374]).

Именуемые здесь «франтастами» (Александр Македонский, Наполеон) одновременно и гиперреалисты. Вот оно, предельное, пожалуй, противоречие, удержать и положительно снять которое способен только человек с характером, и никто иной.

Заключение. Не симпатизируя Ленину-философу (всё-таки догматик, несмотря на некоторые мощные интуиции), но уважая Ленина-политика (ниспровергатель 
эксплуатации, борец, свободный от догматизма в собственно революционной теории и практике), не веря в коммунизм и с омерзением относясь к капитализму (это, увы, даже не ненависть - как бы научиться его ненавидеть?), чаще защищаю сегодня большевистскую линию, нежели критикую её (см., например: [13]). По совести гово- ря, делаю ставку на невульгарно натурных людей. На тех, у кого интересы имеют основанием характер, не наоборот, не как у рацио-мещанина. Не уверен, что характерный археоавангард кардинально изменит к лучшему общую социальную ситуацию. Но именно ему охранять и крепить человеческое достоинство.

\section{Список литературы}

1. Бердяев Н. А. Истоки и смысл русского коммунизма. Репр. воспроизведение изд. YMCA-PRESS, 1955 г. М.: Наука, 1990. 224 с.

2. Валентинов Н. Малознакомый Ленин. СПб.: Мансарда: Смарт, 1991. 154 с.

3. Вернадский Г. В. Ленин - красный диктатор / пер. с англ. В. С. Антонова. М.: Аграф, 1998. 311 с.

4. Горький М. В. И. Ленин (первая редакция). URL: http://www.gorkiy-lit.ru/gorkiy/vospominaniya/v-ilenin-pervaya-redakciya.htm (дата обращения: 02.01.2020). Текст: электронный.

5. Гуревич П. С. Социально-психологические иллюзии Великого Октября // Революция, эволюция и диалог культур: доклады к 100-летию русской революции на Всемирном дне фрилософии в Институте философиии РАН (14-16 ноября 2017 г.) / отв. ред. А. В. Черняев. М.: Гнозис, 2018. С. 277-297.

6. Камю А. Записные книжки (май 1935 - март 1951) / пер. с фр. О. Гринберг, В. Мильчиной // Сочинения: в 5 т. Т. 5. Харьков: Фолио, 1998. 410 с.

7. Лоренц К. Агрессия (так называемое зло). К естественной истории агрессии // Так зазываемое зло / пер. с нем. А. И. Фёдорова; под ред. А. В. Гладкова. М.: Культурная революция, 2008. С. 85-308.

8. Ницше Ф. По ту сторону добра и зла. Прелюдии к философии будущего / пер. с нем. Н. Н. Полилова // Полное собрание сочинений: в 13 т. Т. 5. М.: Культурная революция, 2005-2013. С. 7-227.

9. Серж В. От революции к тоталитаризму: воспоминания революционера. Оренбург: Оренбургская книга: Праксис, 2001. 696 с.

10. Суханов Н. Н. Записки о революции: в 3 т. Т. 2. М.: Политиздат, 1991-1992. Кн. 3-4. 399 с.

11. Устрялов Н. В. Памяти В.И.Ленина // Национал-большевизм. М.: Эксмо, 2003. С. 372-376.

12. Фатенков А. Н. Антропология М. Горького взглядом из капиталистического сегодня // Гуманитарный вектор. 2019. Т. 14, № 2. С. 48-57.

13. Фатенков А. Н. Понять прошлое с достоверностью настоящего: вековые смыслы Русской революции // Философия хозяйства. 2017. № 5. С. 45-53.

14. Фрайер Х. Революция справа / пер. с нем. Ю. Ю. Коринца. М.: Праксис, 2008. 144 с.

15. Шпенглер О. Закат Европы. Очерки морфологии мировой истории. Т. 1. Гештальт и действительность / пер. с нем. К. А. Свасьяна. М.: Мысль, 1993. 663, [1] с.

16. Юнгер Э. Уход в Лес / пер. с нем. А. Климентова. [Б. М., б. и.]. 2014. 149 с.

Статья поступила в редакцию 15.01.2020; принята к публикации 23.02.2020

\section{Сведения об авторе}

Фатенков Алексей Николаевич, доктор философских наук, профессор, Национальный исследовательский Нижегородский государственный университет им. Н. И. Лобачевского; 603950, Россия, г. Нижний Новгород, пр-т Гагарина, 23; Приволжский исследовательский медицинский университет; 603005, Россия, г. Нижний Новгород, пл. Минина и Пожарского, 10/1; e-mail: fatenkov@fsn.unn.ru; https://orcid. org/0000-0001-8628-2413.

\section{Библиографическое описание статьи}

Фатенков А. Н. Антропологическая вертикаль: власть характера над амбициями и интересами // Гуманитарный вектор. 2020. T. 15, № 2. C. 66-75. DOI: 10.21209/1996-7853-2020-15-2-66-75.

\section{References}

1. Berdyaev, N. A. The Origin of Russian Communism. M: Nauka Publ., 1999. (In Rus.)

2. Valentinov, N. Little-known Lenin. St. Petersburg: Mansarda, Smart Publ., 1991. (In Rus.)

3. Vernadsky, G. Lenin, Red Dictator. Moscow: Agraf Publ., 1999. (In Rus.)

4. Gorky, M. V. I. Lenin (First Edition). Web. 02.01.2020. http://www.gorkiy-lit.ru/gorkiy/vospominaniya/ v-i-lenin-pervaya-redakciya.htm. (In Rus.)

5. Gurevich, P. S. Socio-psychological Illusions of the Great October Revolution, in: Revolution, Evolution and Dialogue of Cultures (ed. by A. V. Chernyaev). M: Gnozis Publ., 2018: 277-297. (In Rus.) 
6. Camus, A. Notebooks <May 1935 - March 1951>, in: A. Camus, Works, vol. 5. Kharkiv: Folio Publ., 1998. (In Rus.)

7. Lorenz, K. On Aggression, in: K. Lorenz, The So Called Evil. M: Kul'turnaya revolyutsiya Publ., Moscow, 2008: 85-308. (In Rus.)

8. Nietzsche, F. Beyond Good and Evil, in: F. Nietzsche, Complete Works, vol. 5. M: Kul'turnaya revolyutsiya Publ., Moscow, 2005-2013. PP. 7-227. (In Rus.)

9. Serge, V. Memoirs of a Revolutionary. Orenburg: Orenburgskaya kniga, NPTs «Praksis» Publ., 2001. (In Rus.)

10. Sukhanov, N. N. Notes on the Revolution. Vol. 2. M: Politizdat Publ., 1991-1992. (In Rus.)

11. Ustryalov, N. V. In Memory of V. I. Lenin, in: N. V. Ustryalov, National Bolshevism. Moscow: Eksmo Publ., 2003: 372-376. (In Rus.)

12. Fatenkov, A. N. M. Gorky's Anthropology from the Capitalist Today's Perspective. Humanitarian Vector, no. 2, pp. 48-57, 2019. (In Rus.)

13. Fatenkov, A. N. To Understand that Past with Realness of Present: Eternal Senses of Russian Revolution. Filosofiya khozyaistva, no. 5, pp. 45-53, 2017. (In Rus.)

14. Freyer, H. Revolution from the Right. M: Praxis Publ., 2008. (In Rus.)

15. Spengler, O. The Decline of the West: Outlines of a Morphology of World History. M: Mysl' Publ., 1993. (In Rus.)

16. Jünger, E. The Forest Passage. Transleted from German by A. Klimentov. [S. I., s. n.], 2014. (In Rus.)

Received: January 15, 2020; accepted for publication February 23, 2020

\section{Information about author}

Fatenkov Aleksey N., Doctor of Philosophy, Professor, Lobachevsky State University of Nizhny Novgorod; 23 Gagarina ave., Nizhny Novgorod, 603950, Russia; Privolzhskiy Research Medical University; 10/1 Minin sq., Nizhny Novgorod, 603005, Russia; e-mail: fatenkov@fsn.unn.ru; https://orcid.org/0000-0001-8628-2413.

\section{Reference to the article}

Fatenkov A. N. Anthropological Chain: Power of Character over Ambitions and Interests // Humanitarian Vector. 2020. Vol. 15, No. 2. PP. 66-75. DOI: 10.21209/1996-7853-2020-15-2-66-75. 